\title{
PENGARUH PENGGUNAAN APLIKASI CISCO PACKET TRACER TERHADAP MINAT DAN HASIL BELAJAR SISWA KELAS X TKJ1 PADA MATA PELAJARAN KOMPUTER JARINGAN DASAR DI SMK NEGERI 1 KENDIT SITUBONDO
}

\author{
Luqman Hakim, Rahmat Shofan Razaqi \\ Pendidikan Teknologi Informasi STKIP PGRI Situbondo \\ Email:luqmanhakim@gmail.com
}

\begin{abstract}
Abstrak
Penelitian ini dilatar belakangi rendahnya hasil belajar siswa kelas X TKJ1 di SMK Negeri 1 Kendit Situbondo. Hal ini dibuktikan dari hasil belajar ujian semester yang masih banyak dibawah criteria KKM yang ditetapkan yaitu 7.00 penelitian ini bertujuan untuk mengungkap apakah hasil belajar dengan menggunakan media pembelajaran Cisco Packet Tracer lebih baik dari yang tidak menggunakan. Penelitian ini menggunakan sampling jenuh. Menetapkan jumlah responden 26 siswa Kelas X TKJ1 SMK Negeri 1 Kendit sebagai responden penelitian yang diambil secara sampling jenuh dengan cara diambil seluruh populasi. metode pengumpulan data yang digunakan dalam penelitian ini adalah metode observasi, metode angket, metode interview dan metode dokumentasi. Data yang diperoleh dianalisis dengan menggunakan analisa regresi. Dari hasil penelitian terlihat bahwa ada pengaruh Penggunaan Aplikasi Cisco Paket Tracer terhadap minat sebesar $(-0,452)$ dan hasil belajar sebesar $(-0,463)$ siswa Kelas X TKJ1 pada mata pelajaran komputer jaringan dasar di SMK Negeri 1 Kendit Situbondo dengan pengaruh sedang. Dengan demikian hipotesis yang dikemukakan sebelumnya dapat diterima pada taraf kepercayaan 95\%. Hal ini disebabkan karena pada media pembelajaran Cicso Packet Tracer siswa dibimbing untuk dapat menggunakan kemampuan potensinya.
\end{abstract}

Kata Kunci: Penggunaan Aplikasi Cisco Packet Tracer, Minat, Dan Hasil Belajar

\section{Abstract}

This research is the background of the learning outcomes of class X TKJ1 students at SMK Negeri 1 Kendit Situbondo. This is evidenced from the results of the semester exam learning which is still more than the KKM criteria set at 7.00. This research reveals whether learning outcomes using Cisco Packet Tracer learning media are better than those not used. This research uses saturated sampling. Determine the number of respondents 26 students of class X TKJ1 Vocational School 1 Kendit as a research respondent was taken as a saturated sample by taking the entire population. Data collection methods used in this study were the observation method, the questionnaire method, the interview method and the documentation method. The data obtained were analyzed using regression. Cisco Tracking Application Package for (-0,452) interests and 
learning outcomes (-0,463) Class X TKJ1 students in basic network computer subjects at SMK Negeri 1 Kendit Situbondo by using this time. Thus the hypothesis stated earlier can be accepted at the $95 \%$ confidence level. This is because in the learning media of the Cicso Tracking Package students are guided to be able to use their potential abilities.

Keywords: Use of Cisco Tracer Package Applications, Interests, and Learning Outcomes

\section{PENDAHULUAN}

Pembelajaran pada hakikatnya merupakan kegiatan mental yang tidak dapat dilihat. Hal ini hanya dapat terlihat dari adanya gejala-gejala perubahan perilaku yang tampak. Pembelajaran juga harus dibuat menarik dan unik. Untuk itu diperlukan suatu media pembelajaran yang dapat berfungsi sebagai pengganti dalam pengamatan. Pengamatan dalam hal ini berarah pada apakah pembelajaran yang diberikan pada siswa diterima dengan baik.

Melalui pemanfaatan media pembelajaran diharapkan konsep-konsep ilmu Teknik Komputer dan Jaringan yang bersifat abstrak akan semakin mudah untuk dipahami oleh siswa. Karena salah satu fungsi media adalah dapat membuat konsep abstrak menjadi konkret. Agar penggunaan media dapat mengenai sasaran yaitu tercapainya tujuan pembelajaran serta menemukan jenis-jenis media yang cocok untuk diterapkan maka kreativitas guru dan pihak sekolah sangat diperlukan

Media merupakan sumber-sumber belajar yang potensial apabila dirancang dan digunakan secara baik. Rancangan pembuatan media terdiri dari perencanaan pembuatan media, pemilihan media yang tepat, serta pemanfaatan dan keefektivan dari media yang digunakan. Selain itu, guru harus memiliki kreativitas untuk dapat merancang media pembelajaran. Seperti membuat bagan dan gambar-gambar yang kreatif dalam menguraikan topik pembelajaran tentang Perancangan Wide Area Network (WAN) akan lebih menggugah perhatian dan minat belajar siswa dalam memahami topik tersebut.

Media pembelajaran merupakan suatu alat yang sangat membantu siswa dalam menerima informasi. Secara umum manfaat media dalam proses pembelajaran adalah untuk memperlancar interaksi antara guru dengan siswa sehingga dalam kegiatan pembelajaran yang dirancang dengan baik dapat merangsang pikiran, perasaan, perhatian, dan kemauan siswa sehingga dapat mendorong terjadinya proses kegiatan pada diri siswa. Sehingga minat belajar pun semakin tinggi. 
Ibnu Hajar, (2014) menyatakan bahwa:

1. Belajar lebih banyak terjadi jika media diintegrasikan ke dalam program instruksional yang tradisional.

2. Jumlah belajar yang setara sering dapat tercapai dalam waktu yang lebih singkat dengan menggunakan teknologi.

3. Program instruksional menggunakan berbagai media yang didasarkan pada suatu pendekatan sistem, seringkali memudahkan siswa dalam belajar secara lebih efektif.

4. Program-program media dan atau tutorial audio untuk pembelajaran biasanya lebih disukai siswa bila dibandingkan dengan pengajaran tradisional.

Pembelajaran yang dikembangkan diharapkan dapat meningkatkan penguasaan konsep, keterampilan berpikir kreatif dan keterampilan proses siswa. Selain itu keberhasilan pembelajaran yang dikembangkan dapat di harapkan menjadi percontohan dari pembelajaran sejenis, untuk topiktopik bahan kajian yang lain dalam bidang studi dengan beberapa penyesuaian yang diperlukan.

Seperti kenyataannya, hasil belajar siswa pada mata pelajaran perancangan Wide Area Network (WAN) masih rendah. Dari survei yang dilakukan di lapangan dengan mendengar pendapat guru mata pelajaran bahwasanya hasil belajar siswa kelas $\mathrm{X}$ TKJ untuk mata pelajaran Perancangan Wide Area Network (WAN) dianggap rendah yaitu nilai rata-rata 6,5 masih lebih rendah dari nilai kriteria ketuntasan minimal (KKM) yang ditetapkan oleh Depdiknas yaitu 7,0. Selama proses belajar, minat siswa sangat rendah hal ini bisa dilihat dari rata-rata jumlah kehadiran siswa saat pembelajaran berlangsung berkisar $<80 \%$ per harinya.

Saat pembelajaran berlangsung, guru lebih sering menggunakan metode ceramah dan media yang digunakan hanya media power point. Agar lebih menghemat waktu dan agar kompetensi pembelajaran cepat terselesaikan. Penyebab lain penggunaan metode dikarenakan 1) kurangnya jumlah perangkat jaringan, sehingga siswa dalam melakukan praktek harus bergantian antara satu dengan lainnya atau melakukan praktek secara berkelompok, 2) proses praktek memakan waktu yang cukup lama, dikarenakan siswa harus secara fisik. melakukan konfigurasi jaringan, disamping minimnya jumlah peralatan praktek,

3) sulitnya melakukan praktek pada topik-topik tertentu yang diakibatkan tidak tersedianya peralatan praktek, 4) kesulitan dalam mencari pemecahan masalah bila ditemukan kendala (error) pada peralatan praktek.

Salah satu cara yang bisa dilakukan untuk menyelesaikan permasalahan tersebut adalah dengan memanfaatkan software simulasi 
jaringan yang merupakan program simulasi networking yang dapat menciptakan sebuah jaringan dengan jumlah yang besar. Software simulasi keluaran vendor perangkat jaringan komputer yang terkenal, yaitu CISCO. Penggunaan simulator Packet Tracer memungkinkan setiap siswa dapat bereksplorasi membangun jaringan computer dengan komponen-komponen perangkat jaringan bermacam-macam. Siswa dapat menempatkan perangkat jaringan maupun melakukan konfigurasi pada perangkat jaringan layaknya pada kondisi nyata.

Dari hasil observasi peneliti di lokasi penelitian menyatakan bahwa

guru kurang mengekspresikan kemampuan mengajarnya dan mengefektifkan ketersediaan media pembelajaran yang ada sehingga mata pelajaran perancangan Wide Area Network (WAN) menjadi sangat membosankan. Untuk itu, guru harus menggunakan media pembelajaran yang mendukung proses pembelajaran, selain itu diperlukan kecermatan guru dalam menyampaikan memilih isi materi pembelajaran. Sehingga secara signifikan minat belajar siswa terhadap mata pelajaran Perancangan Wide Area Network (WAN) akan meningkat.

Apabila minat belajar siswa tinggi, maka prestasi akan tercapai. Tetapi apabila minat belajar rendah maka prestasi sulit untuk diraih. Untuk mendukung agar minat belajar siswa meningkat maka dibutuhkan suatu media pembelajaran yang dapat menunjang proses belajar mengajar. Pada dasarnya tidak ada satu pun media yang paling baik untuk semua siswa dan semua pokok bahasan atau pun pokok pelajaran. Oleh karena itu, diperlukan kecermatan guru dalam memilih media.

Packet Tracer adalah sebuah aplikasi simulator alat-alat jaringan cisco yang sering digunakan sebagai media pembelajaran dan pelatihan, dan juga dalam bidang penelitian simulai jaringan computer. Dan tujuan utama dari Packet Tracer ini adalah untuk menyediakan alat bagi siswa dan pengajar agar dapat memahasi prinsip jaringan komputer dan juga membangun skill di bidang alat-alat jaringan cisco.

Fungsinya adalah untuk merancang sebuah sistem atau topologi jaringan yang akan diterapkan pada dunia nyata, apabila kita membuat topologi jaringan komputer tanpa bantuan aplikasi ini biasanya membutuhkan biaya yang sangat mahal. Aplikasi ini biasanya digunakan siswa Cisco Networking Academy melalui sertifikasi Cisco Certified Network Associate (CCNA). Dikarenakan batasan pada beberapa fiturnya, software ini digunakan hanya sebagai alat bantu belajar, bukan sebagai pengganti Cisco routers dan switches. Packet Tracer memungkinkan siswa untuk merancang kompleks dan besar jaringan, yang sering tidak layak dengan hardware fisik, di karenakan biaya. Packet Tracer biasanya digunakan oleh siswa CCNA Academy, karena tersedia untuk mereka 
Kelebihannya:

1. Dapat meningkatkan kreativitas individu karena pembelajaran dilakukan sendiri.

2. Dimungkinkan siswa untuk mengeluarkan ide atau gagasan secara baik dan sistematis.

3. Dapat mengurangi biaya besar untuk melakukan kegiatan pembuatan jaringan.

4. Pembelajaran akan lebih menarik sebab media yang dipakai berupa visual atau gambar.

5. Dapat melakukan rancangan suatu topologi jaringan dengan mudah serta penempatan perangkat jaringan dapat diatur dan ditentukan dengan baik.

Kekurangannya:

1. Untuk melatih alur kemampuan siswa untuk belajar melalui media sangatlah sulit.

2. Media yang diterampilkan adakalanya susah dipahami oleh siswa.

3. Media yang ditampilkan memiliki komponen fisik yang terbatas.

4. Permasalahan yang diajukan adakalanya tidak sesuai dengan daya nalar siswa.

5. Harus membutuhkan konsentrasi yang tinggi, sementara siswa sudah diajak kosentrasi penuh atau totalitas.

Jaringan komputer diartikan sebagai koneksi dua atau lebih komputer yang dihubungkan dengan menggunakan sebuah sistem komunikasi. Jaringan komputer adalah sebuah sistem yang menggunakan teknik komunikasi data, tetapi lebih mementingkan arti dari tiap bit saat proses pengiriman data sampai diterimanya data secara sempurna di komputer yang menjadi tujuannya. Pada jaringan komputer memungkinkan proses pengiriman data dapat berlangsung cepat dan efisien. Kemudian komputer berskala kecil yang disebut personal computer atau PC mulai menggeser komputer-komputer mainframe. Beberapa buah PC dapat membentuk network yang di sebut LAN yang menyediakan pemakaian resource bersama seperti berbagi file. (Sofana, 2012:107).

Versi saat ini dari Packet Tracer mendukung sebuah array dari protocol Application Layer simulasi, serta dasar routing dengan RIP, OSPF, dan EIGRP, sejauh diperlukan oleh kurikulum CCNA saat ini. Sementara Packet Tracer bertujuan untuk memberikan simulasi realistis dari jaringan fungsional, aplikasi itu sendiri hanya menggunakan sejumlah kecil fitur yang ditemukan dalam perangkat keras yang sebenarnya menjalankan versi Cisco IOS saat ini. Jadi, Packet Tracer ini tidak cocok untuk pemodelan jaringan produksi. Dengan diperkenalkannya versi 5.3, beberapa fitur baru yang ditambahkan, termasuk BGP. BGP bukan bagian dari kurikulum CCNA, tetapi bagian dari kurikulum CCNP. 
Packet Tracer adalah sebuah program simulasi jaringan yang kuat yang memungkinkan siswa untuk bereksperimen dengan perilaku jaringan dan bertanya "bagaimana jika" pertanyaan. Sebagai bagian integral dari pengalaman belajar Networking Academy komprehensif, Packet Tracer menyediakan simulasi, visualisasi, authoring, penilaian, dan kemampuan kolaborasi dan memfasilitasi mengajar dan belajar dari konsep teknologi yang kompleks. Packet Tracer memberikan pengalaman terhadap peralatan fisik di kelas secara simulasi dengan memungkinkan siswa untuk membuat jaringan dengan jumlah tak terbatas perangkat, mendorong praktik, penemuan, dan pemecahan masalah. Packet Tracer melengkapi kurikulum Networking Academy, memungkinkan instruktur untuk dengan mudah mengajar dan menunjukkan konsep teknis yang kompleks dan sistem jaringan desain.

Berdasarkan uraian tersebut dapat disimpulkan bahwa packet tracer adalah sebuah router Cisco simulator yang dapat digunakan dalam pelatihan dan pendidikan, tetapi juga dalam penelitian untuk simulasi jaringan komputer sederhana. Alat ini dibuat oleh Cisco Systems dan diberikan untuk dibagikan secara gratis kepada staf pengajar, mahasiswa, dan alumni yang sedang atau telah berpartisipasi dalam Cisco Networking Academy. Tujuan dari packet tracer adalah untuk menawarkan siswa dan guru sebuah alat untuk mempelajari prinsip-prinsip jaringan serta mengembangkan keterampilan teknologi Cisco tertentu.

Minat diartikan sebagai rasa tertarik yang ditunjukkan oleh individu kepada suatu objek, baik objek berupa benda hidup maupun benda yang tidak hidup (Hadis dan Nurhayati, 2010:44). Minat besar sekali pengaruhnya terhadap belajar sebab dengan minat seseorang akan melakukan sesuatu yang diminatinya. Sebaliknya, tanpa minat seseorang tidak mungkin melakukan sesuatu (Winkel, 2004:30). Minat adalah rasa lebih suka dan rasa ketertarikan pada suatu hal atau aktivitas, tanpa ada yang menyuruh (Slameto, 2013:121). Minat dapat timbul dengan sendirinya, yang ditengarai dengan adanya rasa suka terhadap sesuatu.

Crow and crow (dalam Djaali, 2010:121) mengatakan bahwa minat berhubungan dengan gaya gerak yang mendorong seseorang untuk menghadapi atau berurusan dengan orang, benda, kegiatan, pengalaman yang dirangsang oleh kegiatan itu sendiri. Hidi, Renninger \& Krapp (Ormrod, 2010:101) Minat pada dasarnya adalah penerimaan akan suatu hubungan antara diri sendiri dengan sesuatu di luar diri. Semakin kuat atau dekat hubungan tersebut, semakin besar minat.

Minat terhadap sesuatu merupakan hasil belajar dan menyokong belajar selanjutnya (Slameto, 2013:180). Minat merupakan sumber motivasi yang mendorong orang untuk melakukan apa yang mereka inginkan bila mereka bebas memilih (Hurlock, 2011:114). Sedangkan 
belajar dapat diartikan sebagai aktivitas yang dilakukan individu secara sadar untuk mendapatkan sejumlah kesan dari apa yang telah dipelajari dan sebagai hasil dari interaksinya dengan lingkungan sekitarnya (Djamarah, 2011:2).

Soemanto (2016:104) belajar merupakan proses dimana tingkah laku ditimbulkan atau diubah melalui praktek atau latihan. Belajar adalah kegiatan yang berproses dan merupakan unsur yang sangat fundamental dalam penyelenggaraan setiap jenis dan jenjang pendidikan (Syah, 2010: 63). Perubahan akibat belajar itu akan bertahan lama, bahkan sampai taraf tertentu, tidak menghilang lagi. Kemampuan yang telah diperoleh menjadi milik pribadi yang tidak akan hilang begitu saja (Winkel, 2014:57).

Sedangkan pengertian minat belajar adalah aspek psikologi seseorang yang menampakkan diri dalam beberapa gejala, seperti: gairah, keinginan, perasaan suka untuk melakukan proses perubahan tingkah laku melalui berbagai kegiatan yang meliputi mencari pengetahuan dan pengalaman.

Minat belajar itu adalah perhatian, rasa suka, ketertarikan seseorang (siswa) terhadap belajar yang ditunjukkan melalui keantusiasan, partisipasi dan keaktifan dalam belajar (Widyastuti, 2012:5-6). Dapat disimpulkan, minat belajar adalah rasa suka dan merasa tertarik serta keingintahuan pada suatu pelajaran yang ditunjukkan dengan partisipasi dan keaktifan nya ketika pelajaran berlangsung untuk mencapai tujuannya dan melakukan proses perubahan tingkah laku sebagai hasil dari pengalaman individu dalam interaksi dengan lingkungannya.

Ciri-ciri minat menurut Hurlock (1978:114) adalah: 1) Minat tumbuh bersamaan dengan perkembangan fisik dan mental 2) Minat bergantung pada kesiapan belajar 3) Minat bergantung pada kesempatan belajar 4) Perkembangan minat mungkin terbatas 5) Minat dipengaruhi budaya 6) Minat berbobot emosional 7) Minat cenderung bersifat egosentris.

Indikator minat ada empat, menurut Safari (Wasti, 2013:8). a. Perasaan Senang b. Ketertarikan Siswa c. Perhatian Siswa d. Keterlibatan Siswa. Aspek-aspek Minat Minat terdiri dari dua aspek (Hurlock, 2011:116-117). Yaitu: a. Aspek Kognitif b. Aspek Afektif. Unsur-unsur minat meliputi dua hal, yaitu: a) Perhatian, adalah banyak sedikitnya kesadaran yang menyertai sesuatu aktivitas yang dilakukan (Suryabrata, 2008:14-15). b) Motif Menurut Suryabrata (2008:70) motif adalah keadaan dalam pribadi orang yang mendorong individu untuk melakukan aktivitas-aktivitas tertentu guna mencapai suatu tujuan.

Minat belajar adalah rasa tertarik yang ditunjukkan oleh peserta didik dalam melakukan aktivitas belajar, baik di rumah, di sekolah dan di masyarakat (Hadis dan Nurhayati, 2010:44). Hal yang menjadikan siswa 
berminat belajar terhadap suatu pelajaran adalah siswa akan selalu memperhatikan dan mengingat secara terus menerus karena ia senang atau suka dengan pelajaran tersebut (Faizah, 2010:15).

Menurut Lester. D. Crow dan Alice Crow (Kholis, 2010:45-47) ada beberapa faktor yang dapat mempengaruhi tumbuh berkembangnya minat, yaitu:

a. Faktor internal, merupakan faktor dari diri sendiri, yang meliputi antara lain:

1) Motivasi, ini mengarah pada suatu tujuan yang diinginkan dicapai dengan mempertimbangkan dan menyeleksi perbuatan yang akan dikerjakan demi mencapai tujuan yang diinginkan.

2) Kebutuhan, ini dipengaruhi dari usia seseorang. Misalkan, awal masa dewasa muda (usia 22-25 tahun), sering disebut juga masa berharap bekerja (job hopping).

3) Sikap terhadap obyek, Sikap senang terhadap obyek dapat memperbesar minat seseorang terhadap obyek. Sebaliknya, jika sikap tidak senang terhadap obyek, maka akan memperkecil pula minat terhadap obyek.

4) Tingkat Kecerdasan, seseorang yang cerdas dapat mengkondisikan diri untuk menentukan apakah berminat atau tidak dengan memilah dan mempertimbangkan yang hendak dilakukan.

5) Kesehatan, kondisi organ-organ tubuh seperti kebugaran jasmani, kesehatan mata dan telinga serta kepenuhan gizi, mempengaruhi minat seseorang.

b. Faktor eksternal, yaitu kondisi lingkungan sekitar siswa, baik lingkungan sosial maupun lingkungan non sosial, yang meliputi:

1) Lingkungan sosial meliputi lingkungan keluarga, lingkungan sekolah, dan lingkungan masyarakat. Lingkungan keluarga sangat berpengaruh dalam diri siswa.

2) Lingkungan non sosial meliputi gedung sekolah dan letaknya, rumah tempat tinggal dan letaknya, alat-alat belajar, keadaan cuaca, waktu belajar dan sebagainya.

Hasil belajar adalah perubahan perilaku yang terjadi dalam diri siswa atau keberhasilan yang dicapai siswa setelah menerima pembelajaran (Noervadila \& Meiliana, 2019). Menunjuk pemikiran Gagne, hasil belajar berupa hal-hal berikut:

1) Informasi verbal, yaitu kapabilitas mengungkapkan pengetahuan dalam bentuk bahasa, baik lisan maupun tertulis. Kemampuan merespons secara spesifik terhadap rangsangan spesifik. Kemampuan tersebut tidak memerluakn manipulasi symbol, pemecahan masalah, maupun penerapan aturan.

2) Keterampilan intelektual, yaitu kemampuan mempersentasikan konsep dan lambing. Keterampilan intelektual terdiri dari kemampuan 
mengkatagorisasi, kemampuan analitis-sintesis fakta-konsep, dan mengembangkan prinsip-prinsip keilmuan. Keterampilan intelektual merupakan kemampuan melakukan aktivitas kognitif bersifat khas.

3) Strategi kognitif, yaitu kecakapan menyalurkan dan mengarahkan aktivitas kognitif. Kemampuan ini meliputi penggunaan konsep dan kaidah dalam memecahkan masalah.

4) Sikap, yaitu kemampuan menerima atau menolak objek berdasarkan penilaian terhadap objek tersebut. Sikap berupa kemampuan menginternalisasi nilai- nilai. Sikap merupakan kemampuan menjadikan nilai-nilai sebagai standar perilaku.

5) Keterampilan motorik, yaitu kemampuan melakakukan serangkaian gerak jasmani dalam urusan dan koordinasi sehingga terwujud otomatisme gerak jasmani.

Menurut Benyamin Bloom (Sudjana Nana 2016:22-23), hasil belajar secara garis besar dibagi menjadi tiga ranah yakni ranah kognitif, ranah afektif dan ranah psikomotoris.

1) Ranah kognitif berkenaan dengan hasil belajar intelektual yang terdiri dari enam aspek yaitu pengetahuan atau ingatan, pemahaman, aplikasi, analisis, sintesis, dan evaluasi. Kedua aspek pertama disebut kognitif tingkat rendah dan keempat aspek berikutnya termasuk kognitif tingkat tinggi.

2) Ranah afektif berkenaan dengan sikap yang terdiri dari lima aspek yaitu penerimaa, jawaban atau reaksi, penilaian, organisasi dan internalisasi.

3) Ranah psikomotoris berkenaan dengan hasil belajar keterampilan dan kemampuan bertindak. Ada enam aspek ranah psikomotoris yaitu gerakan refleks, keterampilan gerakan dasar, kemampuan perceptual, keharmonisan atau ketepatan, gerakan keterampilan kompleks dan gerakan ekspensif dan interpretatif.

Selain itu, Horward Kingsley (Sudjana Nana 2016:22), hasil belajar dibagi menjadi tiga macam yaitu keterampilan dan kebiasaan, pengetahuaan dan pengertian, sikap dan cita-cita. Sesuai dengan beberapa pendapat tersebut maka dapat disimpulkan bahwa hasil belajar adalah kemampuan dalam menguasai dan memahami informasi yang telah dipelajarinya sehingga dapat menunjukkan perubahan. Perubahan tersebut adalah perubahan hasil belajar yang telah dicapai oleh anak setelah menguasai materi pelajaran.

\section{METODE}

Dalam penelitian ini, rancangan penelitian yang digunakan adalah ex-post facto. Menurut Sugiyono (2013:7) ex post facto merupakan suatu penelitian yang dilakukan untuk meneliti peristiwa yang telah terjadi dan 
kemudian merunut ke belakang untuk mengetahui faktor-faktor yang dapat menimbulkan kejadian tersebut. Sedangkan Nana Sudjana dan Ibrahim menjelaskan "ex post facto tersebut menunjukkan kepada perlakuan atau meliputi variable $\mathrm{X}$ (variabel bebas) yang telah terjadi sebelumnya sehingga peneliti tidak perlu memberikan perlakuan lagi tinggal melihat efeknya tersebut terhadap variable Y (variabel terikat)" (2011:56).

Penentuan lokasi penelitian dilakukan secara sengaja (purposive), yaitu cara pengambilan daerah penelitian dengan mempertimbangkan alasan yang diketahui dari daerah penelitian tersebut. Pertimbangan tertentu ini, misalnya orang tersebut dianggap paling tahu tentang apa yang diharapkan peneliti

(Sugiyono, 2013: 124).

Responden penelitian merupakan serangkaian langkah didalam penelitian dengan demikian akan memudahkan dalam menentukan data-data yang diperlukan. "Responden adalah orang merespon atau menjawab pertanyaan- pertanyaan peneliti baik pertanyaan tertulis atau lisan" (Arikunto, 2015:16). Sedangkan menurut Hadi (2013:70) menyatakan bahwa, "responden juga dapat disebut sampel atau contoh adalah sebagai individu yang diselidikinya.

Penelitian menggunakan sampling jenuh adalah teknik penentuan sampel bila semua anggota populasi digunakan sebagai sampel. Hal ini sering dilakukan bila jumlah populasi relatif kecil, kurang dari 30 orang, atau penelitian yang ingin membuat generalisasi dengan kesalahan yang sangat kecil. Maka penelitian ini penulis akan menetapkan jumlah responden 26 siswa Kelas X TKJ1 SMK Negeri

1 Kendit sebagai responden penelitian yang diambil secara sampling jenuh dengan cara diambil seluruh populasi.

Beberapa metode pengumpulan data yang digunakan dalam penelitian ini adalah metode observasi, metode angket, metode interview dan metode dokumentasi. Selanjutnya dalam upaya mencari kebenaran data pengujian hipotesis yang telah diajukan sebelum menganalisis data dilakukan langkah-langkah editing, koding, tabulasi. Jika data terdistribusi normal maka pengujian hipotesis dalam penelitian ini menggunakan analisis regresi sederhana, dengan bantuan program SPSS 22.0. Adapun persamaan regresi linear sederhana pada penelitian ini adalah sebagai berikut:

$$
\begin{aligned}
& Y_{1}=a_{1+} b_{1}=X \\
& Y_{2}=a_{2}+b_{2}=X
\end{aligned}
$$

Dimana:

$Y_{1}$ : Variabel terikat yang diproyeksikan (minat belajar siswa)

$Y_{2}$ : Variabel terikat yang diproyeksikan (hasil belajar siswa) 
$X$ : Variabel bebas (Penggunaan Aplikasi Cisco Packet Tracer)

$a_{1}$ : Konstanta (nilai $Y_{1}$ apabila $X=0$ )

$a_{2}$ : Konstanta (nilai $Y_{2}$ apabila $X=0$ )

$b$ : Koefisien regresi

Untuk mencari Rhitung dengan menggunakan rumus:

$$
R_{y(1,2)}=\frac{\sqrt{b_{1} X_{1} Y b_{2} X_{2} Y}}{Y^{2}}
$$

Kuadratkan nilai ${ }^{R}$ tersebut menjadi ${ }^{2}$.

Hitung nilai $F_{\text {sign }}$ hitung dengan menggunakan rumus:

$$
F_{\text {reg }}=\frac{R^{2} N M_{1}}{M_{1} R^{2}}
$$

Dimana:

$n=$ Banyak Anggota Sampel

$m=$ Banyak Prediktor

Jika $F_{\text {hitung }} F_{\text {tabel }}$, maka tolak $H_{0}$

Sedangkan untuk mengetahui sikap siswa maka akan diambil data siswa pada akhir pertemuan dengan menggunakan lembar kuesioner (angket) terhadap sikap siswa dengan memberikan jawaban tentang pernyataan yang diberikan oleh guru setelah mengikuti pembelajaran dengan menggunakan Aplikasi Cisco Packet Tracer. Angket sikap meliputi jawaban sangat setuju, setuju, kurang setuju, tidak setuju, dan sangat tidak setuju. Setiap siswa dapat mempunyai jawaban yang berbeda, karena tidak ada jawaban yang dianggap salah. Berdasarkan lembar kuesioner (angket) sikap siswa, maka siswa akan mendapatkan skor berdasarkan jumlah masing-masing sub komponen sikap yang ditunjukkan oleh siswa setelah menjawab semua pernyataan yang tertera pada angket. Skor yang diperoleh dari masing-masing siswa adalah skor dari setiap jawaban terhadap pernyataan mengenai sikap siswa. Pada setiap sub komponen sikap diakumulasikan berdasarkan jumlah jawaban siswa. Setelah itu, sikap siswa dideskripsikan secara keseluruhan dan ditarik kesimpulan berupa kecenderungan sikap positif siswa yang tumbuh terhadap pembelajaran dengan menggunakan Aplikasi Cisco Packet Tracer.

\section{HASIL DAN PEMBAHASAN}

\section{Hasil}

Derajat kebebasan untuk menguji signifikansi harga Freg adalah m lawan $(\mathrm{N}-\mathrm{m}-1)$ dalam kasus di atas $\mathrm{db}=1 / 24$. Untuk db lawan 24 itu 
harga Ftabel dengan signifikasi 5\% = 4,26, jadi harga Freg $=6,150753769$ ini signifikan. Berarti hipotesa nihil (Ho) ditolak dan Hipotesa kerja (Ha) diterima. Untuk lebih jelasnya dapat dilihat pada tabel perbandingan dibawah ini:

Tabel 4.12 Perbandingan Fhitung dengan Ftabel

\begin{tabular}{|c|c|c|c|c|c|}
\hline Hipotesis & Fhitung & Ftabel & $\begin{array}{c}\text { Keputusan } \\
\text { Statistik }\end{array}$ & Korelasi & $\begin{array}{c}\text { Keputusan } \\
\text { Akhir }\end{array}$ \\
\hline $\mathrm{Ho}$ & - & - & - & - & Ho ditolak \\
\hline $\mathrm{Ha}$ & 6,150753769 & 4,26 & Signifikan & Berpengaruh & Ha diterima \\
\hline
\end{tabular}

Derajat kebebasan untuk menguji signifikansi harga Freg adalah $\mathrm{m}$ lawan $(\mathrm{N}-\mathrm{m}-1)$ dalam kasus di atas $\mathrm{db}=1 / 24$. Untuk db lawan 24 itu harga Ftabel dengan signifikasi $5 \%=4,26$, jadi harga $F_{r e g}=6,53351145$ ini signifikan. Berarti hipotesa nihil (Ho) ditolak dan Hipotesa kerja (Ha) diterima. Untuk lebih jelasnya dapat dilihat pada tabel perbandingan dibawah ini:

Tabel 4.13: Perbandingan Fhitung dengan Ftabel

\begin{tabular}{|c|c|c|c|c|c|}
\hline Hipotesis & Fhitung & Ftabel & $\begin{array}{c}\text { Keputusan } \\
\text { Statistik }\end{array}$ & Korelasi & $\begin{array}{c}\text { Keputusan } \\
\text { Akhir }\end{array}$ \\
\hline Ho & - & - & - & - & Ho ditolak \\
Ha & 6,53351145 & 4,26 & Signifikan & Berpengaruh & Ha diterima \\
\hline
\end{tabular}

Untuk mengetahui apakah hipotesa mayor yang diajukan terima / ditolak, maka harga rhitung dibandingkan dengan rtabel. Dari hasil perbandingan dengan rhitung dengan taraf signifikansi $5 \%$ dengan jumlah responden 26 orang diperoleh rtabel $=0,374$ sedangkan hipotesa mayor Rxy sebesar $-0,452$.

Dari hasil perbandingan ternyata rhitung lebih besar dari rtabel artinya hipotesa kerja (Ha) diterima dan hipotesa nihil (Ho) ditolak, hipotesa kerja yang diterima adalah: "Ada pengaruh penggunaan Aplikasi Cisco Paket Tracer terhadap minat belajar siswa Kelas X TKJ1 pada mata pelajaran komputer jaringan dasar di SMK Negeri 1 Kendit Situbondo “. Nilai tersebut di atas dikonsultasikan dengan tabel interprestasi koefisien korelasi:

Tabel 4.14 Interprestasi Koefisien Korelasi

\begin{tabular}{|c|c|}
\hline Besar nilai $\mathrm{r}$ & Interprestasi \\
\hline Antara $\pm 0,00 \mathrm{~s} / \mathrm{d} \pm 0,20$ & Tidak ada pengaruh \\
Antara $\pm 0,21 \mathrm{~s} / \mathrm{d} \pm 0,40$ & Pengaruh rendah \\
Antara $\pm 0,41 \mathrm{~s} / \mathrm{d} \pm 0,60$ & Pengaruh sedang \\
Antara $\pm 0,61 \mathrm{~s} / \mathrm{d} \pm 0,80$ & Pengaruh tinggi \\
Antara $+0,81 \mathrm{~s} / \mathrm{d}+1,00$ & \\
\hline
\end{tabular}


Untuk mengetahui apakah hipotesa mayor yang diajukan terima / ditolak, maka harga rhitung dibandingkan dengan rtabel. Dari hasil perbandingan dengan rhitung dengan taraf signifikansi $5 \%$ dengan jumlah responden 26 orang diperoleh rtabel $=0,374$ sedangkan hipotesa mayor Rxy sebesar $-0,463$.

Dari hasil perbandingan ternyata rhitung lebih besar dari rtabel artinya hipotesa kerja (Ha) diterima dan hipotesa nihil (Ho) ditolak, hipotesa kerja yang diterima adalah: "Ada pengaruh penggunaan Aplikasi Cisco Paket Tracer terhadap minat belajar siswa Kelas X TKJ1 pada mata pelajaran komputer jaringan dasar di SMK Negeri 1 Kendit Situbondo “. Nilai tersebut di atas dikonsultasikan dengan tabel interprestasi koefisien korelasi:

Tabel 4.15 Interprestasi Koefisien Korelasi

\begin{tabular}{|c|c|}
\hline Besar nilai $\mathbf{r}$ & Interprestasi \\
\hline Antara $\pm 0,00 \mathrm{~s} / \mathrm{d} \pm 0,20$ & Tidak ada pengaruh \\
Antara $\pm 0,21 \mathrm{~s} / \mathrm{d} \pm 0,40$ & Pengaruh rendah \\
Antara $\pm 0,41 \mathrm{~s} / \mathrm{d} \pm 0,60$ & Pengaruh sedang \\
Antara $\pm 0,61 \mathrm{~s} / \mathrm{d} \pm 0,80$ & Pengaruh tinggi \\
Antara $\pm 0,81 \mathrm{~s} / \mathrm{d} \pm 1,00$ & \\
\hline
\end{tabular}

\section{Pembahasan}

1. Penggunaan Aplikasi Cisco Paket Tracer terhadap minat belajar siswa Kelas X TKJ1 pada mata pelajaran komputer jaringan dasar di SMK Negeri 1 Kendit Situbondo.

Setelah menganalisa data dan pengujian hipotesis, didapat nilai tingkat koefisien korelasi antara penggunaan Aplikasi Cisco Paket Tracer (X) terhadap Minat Belajar Siswa (Y1) sebesar -0,452, sedangkan nilai $\mathrm{F}$ reg $=6,150753769$. Untuk mengetahui signifikan atau tidaknya nilai Freg ini dikonsultasikan dengan Ftabel. Derajat kebebasan untuk menguji signifikansi harga Freg adalah m lawan (N $\mathrm{m}-1$ ) dalam kasus di atas $\mathrm{db}=1 / 24$. Untuk db lawan 24 itu harga Ftabel dengan signifikasi $5 \%=4,26$, jadi harga Freg $=6,150753769$ ini signifikan dengan nilai Efektifitas Garis Regresi (EGR) sebesar $20,42 \%$.

2. Penggunaan Aplikasi Cisco Paket Tracer terhadap hasil belajar siswa Kelas X TKJ1 pada mata pelajaran komputer jaringan dasar di SMK Negeri 1 Kendit Situbondo.

Setelah menganalisa data dan pengujian hipotesis, didapat nilai tingkat koefisien korelasi antara penggunaan Aplikasi Cisco Paket Tracer (X) terhadap Hasil Belajar Siswa (Y2) sebesar -0,463 sedangkan nilai Freg $=6,53351145$. Untuk mengetahui signifikan atau 
tidaknya nilai Freg ini dikonsultasikan dengan Ftabel. Derajat kebebasan untuk menguji signifikansi harga Freg adalah m lawan (N $\mathrm{m}$-1) dalam kasus di atas $\mathrm{db}=1 / 24$. Untuk db lawan 24 itu harga Ftabel dengan signifikasi $5 \%=4,26$, jadi harga Freg $=6,53351145$ ini signifikan dengan nilai Efektifitas Garis Regresi (EGR) sebesar 21,41\%.

\section{KESIMPULAN}

Berdasarkan analisis yang dilakukan untuk pengujian hipotesis yang diajukan dalam penelitian ini, maka dapatlah diambil kesimpulan sebagai berikut:

1. Setelah menganalisa data dan pengujian hipotesis, didapat nilai tingkat koefisien korelasi antara penggunaan Aplikasi Cisco Paket Tracer (X) terhadap Minat Belajar Siswa (Y1) sebesar -0,452, sedangkan nilai $F_{r e g}=6,150753769$. Untuk mengetahui signifikan atau tidaknya nilai Freg ini dikonsultasikan dengan Ftabel. Derajat kebebasan untuk menguji signifikansi harga Freg adalah m lawan (N - $\mathrm{m}$-1) dalam kasus di atas $\mathrm{db}=1 / 24$. Untuk db lawan 24 itu harga Ftabel dengan signifikasi $5 \%=4,26$, jadi harga $F_{r e g}=6,150753769$ ini signifikan dengan nilai Efektifitas Garis Regresi (EGR) sebesar 20,42\% sehingga dapat disimpulkan ada pengaruh Penggunaan Aplikasi Cisco Paket Tracer terhadap minat belajar siswa Kelas X TKJ1 pada mata pelajaran komputer jaringan dasar di SMK Negeri 1 Kendit Situbondo sebesar -0,452 dengan pengaruh sedang.

2. Setelah menganalisa data dan pengujian hipotesis, didapat nilai tingkat koefisien korelasi antara penggunaan Aplikasi Cisco Paket Tracer (X) terhadap Hasil Belajar Siswa (Y2) sebesar -0,463 sedangkan nilai Freg $=6,53351145$. untuk mengetahui signifikan atau tidaknya nilai Freg ini dikonsultasikan dengan Ftabel. Derajat kebebasan untuk menguji signifikansi harga Freg adalah m lawan (N - $\mathrm{m}$-1) dalam kasus di atas $\mathrm{db}=1 / 24$. Untuk db lawan 24 itu harga Ftabel dengan signifikasi $5 \%=4,26$, jadi harga $F$ reg $=6,53351145$ ini signifikan dengan nilai Efektifitas Garis Regresi (EGR) sebesar 21,41\%. Sehingga dapat disimpulkan ada pengaruh Penggunaan Aplikasi Cisco Paket Tracer terhadap hasil belajar siswa Kelas X TKJ1 pada mata pelajaran komputer jaringan dasar di SMK Negeri1 Kendit Situbondo sebesar -0,463 dengan pengaruh sedang. 


\section{DAFTAR PUSTAKA}

Arikunto, 2015. Dasar-dasar Evaluasi Pendidikan. Jakarta: Bumi. Aksara. Bambang Soepono, 2014. Statistik Terapan Dalam Ilmu-ilmu Sosial dan Pendidikan. Jakarta:PT Rineka Cipta.

Benyamin Bloom, 2016. Taxonomy of Educational Objective. New York: Longman.

Crow and crow, 2010. Educational Psychology, Amerika: American Book Company.

Daud, Basri, Baki, Hamzah, dan Nawawi, 2011. Model Pembelajaran

Menciptakan Proses Belajar Mengajar yang Kreatif dan Efektif. Jakarta: Bumi Aksara.

Djamarah, 2008. Psikologi Belajar. Jakarta: Rineka Cipta

Noervadila, I., \& Meiliana, A. (2019). Pengaruh Pola Asuh Orang Tua Demokratis Terhadap Hasil Belajar Siswa Pada Mata Pelajaran Matematika Kelas Vii Smpn 1 Situbondo. Jurnal IKA PGSD (Ikatan Alumni PGSD) UNARS, 7(1), 17-30. 